DOI: https://doi.org/10.31933/dijms.v2i3 Received: 15 December 2020, Revised: 25 December 2020, Publish: 25 January 2021

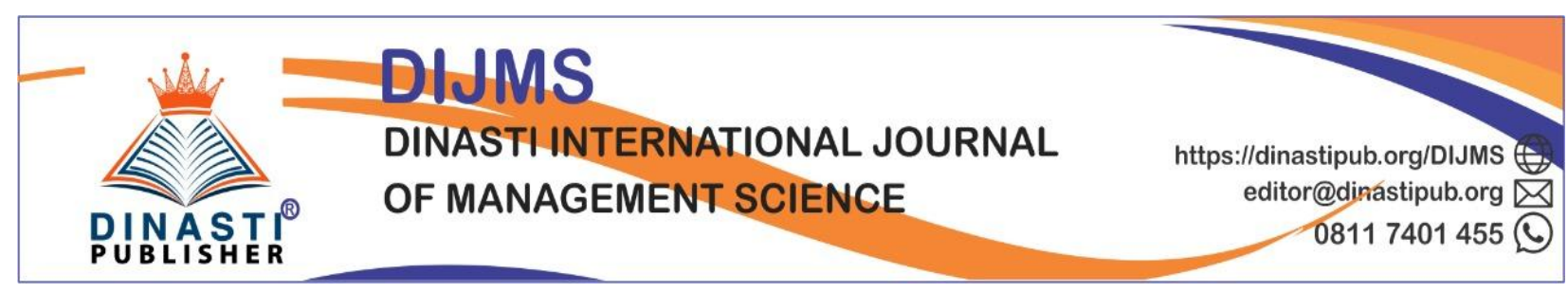

\title{
THE ROLE OF LEADERSHIP, TEAMWORK, AND BUSINESS PROCESS IN AFFECTING THE PERFOMANCE OF ACCOUNT MANAGER AT PT. TELKOM INDONESIA IN SELLING THE VPN PRODUCTS
}

\author{
Febryandoko Febryandoko ${ }^{1}$, Aslam Mei Nur Widigdo ${ }^{2}$ \\ ${ }^{1)}$ Universitas Mercu Buana, Jakarta, Indonesia, benfebryandoko@ gmail.com \\ ${ }^{2)}$ Universitas Mercu Buana, Jakarta, Indonesia, aslam.mw@gmail.com
}

\section{Corresponding Author: Febryandoko}

\begin{abstract}
This research has been purposed to discover and analyze the role of leadership, teamwork and business process on the achievement of account manager in selling the VPN products. These research methods used a quantitative approach by multiple linear regression analysis to examine the hypothesis. The research population and research sample were 85 respondents who work as Account Manager of the Manufacturing Segment, Service Business Division at PT. Telkom throughout Indonesia.The results showed if the leadership, teamwork and business process partially had a positive affect on the performance of the account manager in VPN sales. It also simultaneously affects the account manager's performance in VPN sales.
\end{abstract}

Keywords: Leadership, Teamwork, Business Process, Account Manager' Performance.

\section{INTRODUCTION}

These days, the growth of MSMEs in Indonesia has continued to increase from year to year, this proven by the increase in the number of MSMEs of 12.23 percent during the period of 2010 to 2015 and 2.06 percent in 2016-2017. This rapid growth has also resulted in an increase in the GDP (Gross Domestic Product) from 57.84 percent to 60.34 percent in the same period. This could be the opportunity for PT Telkom to spread its wings in this industry.

As a form of seriousness in supporting the growth of MSMEs, PT Telkom created a Business Service Division (DBS) which has specifically to provide the solutions for MSMEs. In current development, The Telkom DBS focuses on 5 (five) business segments in providing solutions to the needs of MSMEs in Indonesia, such as Manufacture Business Service (MBS), Hospitality Business Service (HBS), Logistic Business Service (LBS) Segments, Trading Business Service (TBS) and Consumer and Contact Center Service (CCS).

As the represented from Telkom DBS itself is carried out by the Account Manager (AM), as the sales person in providing the best solutions to MSME players throughout Indonesia. The 
telecommunications services provided, such as VPN, Metro, and Astinet, are currently the mainstay products which are commonly used by MSME players. These three products provide an ease of use, effectiveness of activities and affordable costs for MSME players in Indonesia. This product remains as the main focus of Telkom DBS sales to this now.

The researchers compared to the sales details of these 3 (three) superior products of Telkom DBS with the distribution per industry segmentation during January - December 2019. Based on the data obtained, it could be seen if Telkom DBS failed to achieve the target expected by management. The biggest drawback could be seen in the sales of VPN (37.43\%), this could be a challenge for 5 segments in Telkom DBS in order to increase the sales and meet management targets.

Table 1. Comparison of Telkom DBS Product Target and its Realization

\begin{tabular}{|c|r|r|c|}
\hline Segmen & Target (Metro) & Realisasi (Metro) & Ach YtD \\
\hline CCS & - & 52 & $0,0 \%$ \\
\hline HBS & 1.450 & 435 & $30,0 \%$ \\
\hline LBS & 1.600 & 262 & $16,4 \%$ \\
\hline MBS & 1.600 & 5.360 & $335,0 \%$ \\
\hline TBS & 1.350 & 600 & $44,4 \%$ \\
\hline Total & 6.000 & 6.709 & $\mathbf{1 1 1 , 8 \%}$ \\
\hline Segmen & Target (Astinet) & Realisasi (Astinet) & Ach YtD \\
\hline CCS & 8.950 & 4.918 & $54,9 \%$ \\
\hline HBS & 10.500 & 13.269 & $126,4 \%$ \\
\hline LBS & 10.500 & 12.656 & $120,5 \%$ \\
\hline MBS & 11.500 & 24.862 & $216,2 \%$ \\
\hline TBS & 11.500 & 7.906 & $68,7 \%$ \\
\hline Total & 52.950 & 63.611 & $\mathbf{1 2 0 , 1 \%}$ \\
\hline Segmen & Target (VPN) & Realisasi (VPN) & Ach YtD \\
\hline CCS & - & 2 & $0,0 \%$ \\
\hline HBS & 300 & 16 & $5,3 \%$ \\
\hline LBS & 350 & 86 & $24,5 \%$ \\
\hline MBS & 350 & 326 & $93,1 \%$ \\
\hline TBS & 250 & 39 & $15,4 \%$ \\
\hline Total & 1.250 & 468 & $37,43 \%$ \\
\hline
\end{tabular}

The biggest weakness from Q1 to Q4 (January - December 2019) at Telkom DBS is in VPN sales. Referring to the Table 1, the contribution of each segment in Telkom DBS to VPN sales which is very low, no segment has been able to achieve the expected target. These numbered of $37 \%$ shows that the need for fast responses from management to get better results. Based on the achievement of VPN sales in the MBS segment nationally, AM still could not capable to sell VPN products as well as selling Astinet products. This matters has becomes source why researchers did this research related to problems faced by the AM MBS segment throughout Indonesia, which are spread across 7 regional Telkom. 
Table 2. Profiling the distribution of VPN sales for the MBS segment throughout Indonesia Comparison of Target and its actual Realized Sales (Bandwidth and Nominal) of VPN for MBS Segment

\begin{tabular}{lccll}
\hline Regional & Target VPN (Mbps) & Real VPN (Mbps) & Target VPN (Rp) & Real VPN $($ Rp) \\
\hline REG-1 & 43 & 40,0 & 7.967 .847 .237 & 5.400 .762 .684 \\
\hline REG-2 & 113 & 105,2 & 20.938 .761 .344 & 25.512 .089 .868 \\
\hline REG-3 & 39 & 36,3 & 7.226 .652 .145 & 5.440 .632 .986 \\
\hline REG-4 & 47 & 43,8 & 8.709 .042 .329 & 5.828 .879 .262 \\
\hline REG-5 & 72 & 67,0 & 13.341 .511 .653 & 14.105 .736 .768 \\
\hline REG-6 & 13 & 12,1 & 2.408 .884 .048 & 1.868 .766 .194 \\
\hline REG-7 & 23 & 21,4 & 4.261 .871 .778 & 2.221 .737 .406 \\
\hline Total & $\mathbf{3 5 0}$ & $\mathbf{3 2 6}$ & $\mathbf{6 4 . 8 5 4 . 5 7 0 . 5 3 5}$ & $\mathbf{6 0 . 3 7 9 . 6 0 5 . 1 6 8}$ \\
\hline
\end{tabular}

Source: Data Management Revenue of Telkom DBS, 2019

Currently, 85 people are assigned to the MBS segment in Indonesia. AM is indeed devoted to providing the MSME solutions to industries in the MBS segment. All AMs has spread across 64 Telkom branches throughout Indonesia with aims that the product could be enjoyed by MSME players wherever they are. However, in the current condition, AM has encountered many obstacles when providing solutions which resulted in suboptimal achievements obtained by the MBS segment AM in VPN sales.

Looking at these current conditions, the researchers tried to see if the factors that hinder AM's performance in selling VPN products. As initial data which was conducted to 30 AM by selecting 2 main indicators using the google sheet application. Based on these pre-survey results, it was found that these 3 main factors were suspected to play a part in influencing the AM performance, such as leadership, teamwork and business processes.

Table 3. AM's pre-survey on the MBS segment's satisfaction

\begin{tabular}{rlcc}
\hline No & \multicolumn{1}{c}{ FaCtor } & Amount & Percentage \\
\hline 1 & Personal (skill) & 4 & $6,67 \%$ \\
$\mathbf{2}$ & Leadership & $\mathbf{9}$ & $\mathbf{1 5 , 0 0 \%}$ \\
$\mathbf{3}$ & Teamwork & $\mathbf{1 0}$ & $\mathbf{1 6 , 6 7 \%}$ \\
$\mathbf{4}$ & Business Process & $\mathbf{1 4}$ & $\mathbf{2 3 , 3 3 \%}$ \\
5 & Conceptual & 4 & $6,67 \%$ \\
6 & Will & 5 & $8,33 \%$ \\
7 & Technology & 3 & $5,00 \%$ \\
8 & Compensation & 7 & $11,67 \%$ \\
9 & Clarity of Purpose & 2 & $3,33 \%$ \\
10 & Security & 2 & $3,33 \%$ \\
\hline \multicolumn{2}{|c}{ Total } & \multicolumn{2}{c}{ Source: Researchers processed results, 2019}
\end{tabular}

Based on the background which has been described above, so then as the research statement is whether the leadership, teamwork and business processes affect the performance of the account manager at PT. Telkom in selling the VPN products either partially or simultaneously?

These research main purposed were to find out and analyze the effects of leadership, teamwork and business processes on the performance of the account manager at PT. Telkom in selling VPN products both partially and simultaneously. 


\section{LITERATURE REVIEW}

According to Mangkunegara in Santoso and Riyanto (2020), Performance is the quality and quantity of results achieved by an employee in carrying out their duties in accordance with the responsibilities assigned to him. Meanwhile, Edison (2016: 190) explained that the notion of achievement as the result of a process that refers and measured over a certain period of time based on predetermined terms or agreements. Gomes (2013:12) explained that there has 5 factors which could improve employee performance such as quality of work, quantity of work, creativity, innovation and initiative.

Wahjosumidjo in Maryani \& Hasbiansyah (2011) defined leadership as a trait inherent in a leader. Meanwhile, Terry in Anzhari, et al (2015) said if leadership was an activity to influence people, so they would be able to achieve organizational goals. According to Kartono (2008), a person who has leadership style could be seen and assessed from several indicators, such as the ability to make decisions, the ability to motivate, the ability to communicate, the ability to control their subordinates, responsibility and the ability to control emotions.

Soekamto in Busro (2018) explained that teamwork is an activity which is carried out jointly by more than one person. Meanwhile, based on Zainudin in Putri, et al (2018) teamwork is the concern of one person or one party to others which is reflected in an activity that could benefit all parties with the principles of mutual trust, respect and the existence of governing norms, the meaning of teamwork in this case is in the organizational context such as work between members of the organization to achieve their goals (all members). Meanwhile, according to Sharma \& Mani (2012:11) the dimensions of teamwork in an organization are clear, open and honest goals in communication, teamwork decision making, an atmosphere of trust, a sense of belonging.

According to Magal \& Word (2012: 4-6), business processes are collections of activities or tasks which produce something. Meanwhile, another opinion states that a business process is a collection of related activities to produce a product or service which has value to the company (Rainer \& Cegielski, 2011:7). There are several characteristics of business processes according to Magal \& Word (2012: 4-6) including definitive, order, customer, extra value, linkages and cross functions.

Prior research by Hwang, et al (2015) it was found that leadership style has a significant affect on employee performance. Charismatic and directive leadership behavior is positively related to the work performance of the leader, the effects of supportive leadership behavior are not as strong as charismatic leadership and directive behavior. Participatory leadership behavior is not related to the performance of leaders in the countries studied except for Japan. While Marpaung (2014) found if the leadership style had a negative and insignificant affect on the performance of cooperative employees at the secretary general, while teamwork had a significant positive affect on the performance of cooperative employees at the secretary general. Leadership and teamwork jointly contribute to the performance of cooperative employees. Research of Umit, et al (2011) shows if there is a significant affect of business process management on employee performance in the company.

Based on prior research and the theories review related to leadership, teamwork, business processes and employee performance, then as the research's conceptual framework model as it shown in Figure 1. 


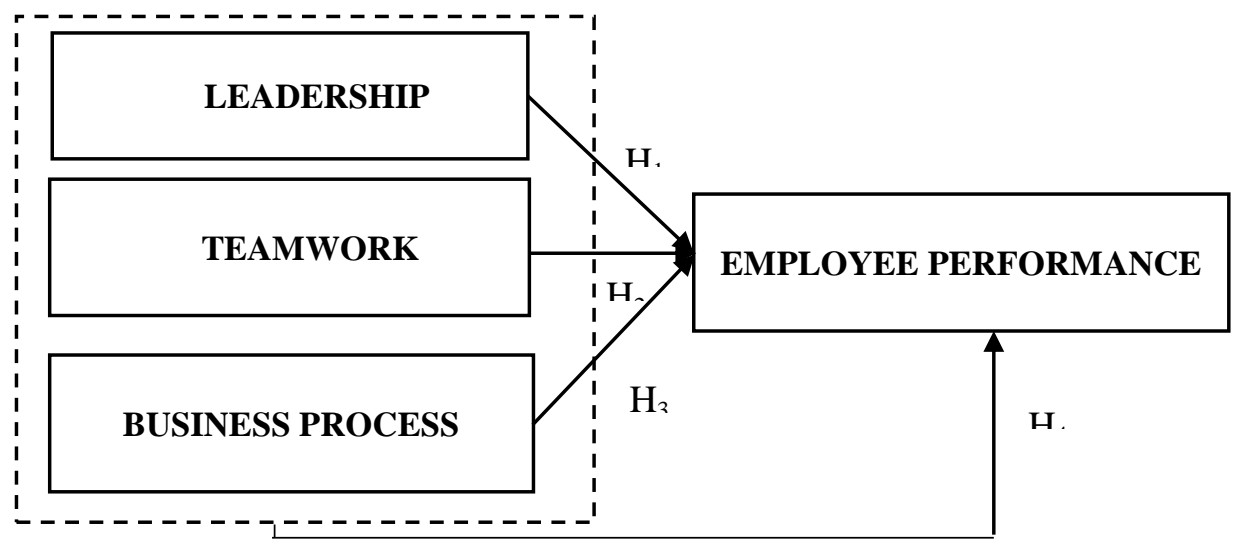

Figure 1. Theoretical Framework

The research hypothesis which arranged could be seen as follows:

1) Leadership has a positive effect on employee performance.

2) Teamwork has a positive effect on employee performance

3) Business Process has a positive effect on Employee performance

4) Leadership, teamwork, Business Process simultaneously have a positive effect on employee performance.

\section{RESEARCH METHODS}

This research uses a descriptive research method with quantitative approach. The research population were all Account Managers from the Manufacturing Segment, Service Business Division at PT. Telkom throughout Indonesia with a numbered of 85 people. The sampling technique in this research was carried out by saturated samples, so the sample in this research was 85 respondents. The research data types included primary data and secondary data, while the research instrument used a questionnaire with Likert scale of 1-5 which was distributed to research respondents to obtain the research data. The research data obtained then analyzed by multiple linear regression analysis through the research instrument test and hypothesis examination.

\section{RESULT AND DISCUSSION Research Result}

The results showed if the t-count of leadership variables was 5.202 5.202 and Sig. 0.000 $<0.05$; t-count of teamwork variable was 2.499 and Sig. $0.014<0.05$; and t-count of business process variables was 3.070 and Sig. $0.003<0.05$, it could be concluded that both leadership variables, teamwork variables, business process variables partially has a positive and significant effect on account manager performance, meaning if the $\mathrm{H} 1, \mathrm{H} 2$, and $\mathrm{H} 3$ were accepted. As for the regression equation obtained from this data processing could be formulated as follows: $\mathrm{Y}=3,924+0.208 \mathrm{X} 1+0.156 \mathrm{X} 2+0.266 \mathrm{X} 3$.

The results from the F test and R2 test shows that F-count was 48.844 and Sig. 0,000 $<$ Sig. 0.05, thus it could be concluded that $\mathrm{H} 4$ which stated if the leadership, teamwork and business processes simultaneously affect the performance of the account manager was 
accepted. The simultaneous effect was $63.1 \%$, while the remaining $36.9 \%$ was determined by other factors outside of this research.

Table Error! No text of specified style in document.. Regression Analysis Results

\begin{tabular}{|c|c|c|c|c|c|c|}
\hline \multirow{2}{*}{\multicolumn{2}{|c|}{ Model }} & \multicolumn{2}{|c|}{ Unstandardized Coefficients } & $\begin{array}{l}\text { Standardized } \\
\text { Coefficients }\end{array}$ & \multirow[b]{2}{*}{$\mathrm{t}$} & \multirow[b]{2}{*}{ Sig. } \\
\hline & & $\mathrm{B}$ & Std. Error & Beta & & \\
\hline 1 & (Constant) & 3.924 & 4.199 & & .935 & .353 \\
\hline & Leadership & .208 & .040 & .455 & 5.202 & .000 \\
\hline & Teamwork & .156 & .062 & .219 & 2.499 & .014 \\
\hline & Business Process & .226 & .074 & .264 & 3.070 & .003 \\
\hline & $\operatorname{ANOVA}\left(\mathbf{F}_{\text {hitung }}\right)$ & & & & 48.844 & .000 \\
\hline & $\mathrm{R}$ (multiple regression) & & & & .802 & \\
\hline & Adjusted R Square & & & & 631 & \\
\hline
\end{tabular}

Source: Data processed (2020)

\section{Inter-Dimensional Correlation}

Based on these inter-dimensional correlation test results, the research findings could be described such as: the dimensions of decision making has a strong and significant correlation with the dimensions of work quantity; the dimension of motivation ability has a moderate and significant correlation with innovation; the dimension of communication skills has a moderate and significant correlation with the quality of work; the dimension of the ability to control subordinates has a moderate and significant correlation with the quality of work; the dimension of responsibility has a moderate and significant correlation with the quality of work; the dimension of the ability to control emotions has a moderate and significant correlation with innovation.

The dimensions of clarity purpose which have a moderate and significant correlation with innovation; open and honest dimensions which have a moderate and significant correlation with the creativity dimension; the cooperative dimension has a moderate and significant correlation with the quality of work; the atmosphere of trust dimension has a moderate and significant correlation with innovation; the dimension of taste has a moderate and significant correlation with creativity.

The definitive dimension has moderate and significant correlation with innovation; the order dimensions are moderately and significantly correlated with initiative; the customer dimensions have a moderate and significant correlation with innovation; the extra value dimension has a moderate and significant correlation with innovation; the linkages dimension has a moderate and significant correlation with innovation; the cross function dimension has a moderate and significant correlation with innovation.

Table 5. Inter-Dimensional Correlation Matrix

\begin{tabular}{lllllll}
\hline \multicolumn{1}{c}{ Dimension } & Code & Y1.1 & Y1.2 & Y1.3 & Y1.4 & Y1.5 \\
\hline Decision Making & $\mathrm{X} 1.1$ & $.592^{* *}$ & $.609^{* *}$ & $.493^{* *}$ & $.470^{* *}$ & $.441^{* *}$ \\
Motivating Ability & $\mathrm{X} 1.2$ & $.486^{* *}$ & $.479^{* *}$ & $.495^{* *}$ & $.514^{* *}$ & $.385^{* *}$ \\
Communication Skills & $\mathrm{X} 1.3$ & $.486^{* *}$ & $.391^{* *}$ & $.333^{* *}$ & $.418^{* *}$ & $.417^{* *}$ \\
Ability To Control Subordinates & $\mathrm{X} 1.4$ & $.452^{* *}$ & $.397^{* *}$ & $.289^{* *}$ & $.411^{* *}$ & $.434^{* *}$ \\
Responsible & $\mathrm{X} 1.5$ & $.536^{* *}$ & $.532^{* *}$ & $.394^{* *}$ & $.487^{* *}$ & $.326^{* *}$ \\
Controlling Emotions Ability & $\mathrm{X} 1.6$ & $.434^{* *}$ & $.446^{* *}$ & $.424^{* *}$ & $.559^{* *}$ & $.305^{* *}$
\end{tabular}




Clear Purpose
Open \& Honest
Cooperative
An Atmosphere of Trust
A Sense of Belonging
Definitive
Order
Customer
Value-added
Linkages
Cross Functions

\begin{tabular}{|c|c|c|c|c|c|}
\hline $\mathrm{X} 2.1$ & $.289^{* *}$ & $.346^{* *}$ & $.447^{* *}$ & $.296^{* *}$ & $.375^{* *}$ \\
\hline $\mathrm{X} 2.2$ & $.251^{*}$ & $.266^{*}$ & $.460^{* *}$ & $.313^{* *}$ & $.240^{*}$ \\
\hline $\mathrm{X} 2.3$ & $.471^{* *}$ & $.409^{* *}$ & $.365^{* *}$ & $.416^{* *}$ & $.304^{* *}$ \\
\hline X2.4 & $.421^{* *}$ & $.401^{* *}$ & $.343^{* *}$ & $.453^{* *}$ & $.396^{* *}$ \\
\hline $\mathrm{X} 2.5$ & $.342^{* *}$ & $.392^{* *}$ & $.442^{* *}$ & $.392^{* *}$ & $.333^{* *}$ \\
\hline X3.1 & $.332^{* *}$ & $.283^{* *}$ & $.229^{*}$ & $.350^{* *}$ & $.343^{* *}$ \\
\hline X3.2 & $.331^{* *}$ & $.230^{*}$ & $.312^{* *}$ & $.308^{* *}$ & $.460^{* *}$ \\
\hline X3.3 & $.397^{* *}$ & $.355^{* *}$ & $.387^{* *}$ & $.435^{* *}$ & $.407^{* *}$ \\
\hline X3.4 & $.377^{* *}$ & $.350^{* *}$ & $.381^{* *}$ & $.430^{* *}$ & $.374^{* *}$ \\
\hline X3.5 & $.304^{* *}$ & $.302^{* *}$ & $.231^{*}$ & $.321^{* *}$ & $.255^{*}$ \\
\hline X3.6 & $.381^{* *}$ & $.309^{* *}$ & $.346^{* *}$ & $.399^{* *}$ & $.330^{* *}$ \\
\hline
\end{tabular}

Source: Data processed (2020)

\section{Discussion}

The results showed if the leadership partially had a positive and significant effect on account manager performance. The findings were according to the leadership theory which said that leadership is an inherent trait in a leader. From these interdimensional correlation test results on the leadership variable relates to account manager performance variable in Telkom when selling VPN products, it could be seen clearly that the lowest inter-dimensional correlation between the dimensions of the ability to control subordinates carried out by superiors has low and significant correlation with the dimension of creativity. Meaning if the account manager's work creativity is low due to the boss's misunderstanding of the account manager's ability to carry out the task of selling VPN products. Then, the boss is unable to maintain steady performance standards. As a result, the account manager often becomes less fast in completing the process of selling VPN products.

Furthermore, the result of the strongest interdimensional correlation occurred in the dimensions of decision making which have a strong and significant correlation with the quantity dimension of work. Meaning if the more enhanced the dimension of decision making, the more the quantity of work done by the account manager will increase. The increase in the quantity of work is due to the ability of superiors to notice those several things personally, such as promoting an account manager who works hard and achieves the expected targets by management. Superiors who provide the motivation by promoting their subordinates to a higher level position will encourage the mood of the account manager to complete with larger number (quantity) of VPN products sales.In addition, superiors would be able to be assertive in determining complex decisions to account managers by providing clear directions in completing the VPN product sales process. That way, the account manager will get motivated to finish selling more VPN products. The boss listens to the complaints which are submitted by the account manager, then provides the solutions to solve problems faced by the account manager so the similar problems encountered in the field could be resolved properly. Superiors were even willing to share information to support the account manager's work activities so there will be more sales and delivery of VPN products.

The results showed if the teamwork partially had a positive and significant effect on account manager performance. These research findings were in accordance with the teamwork theory, which is said as an activity carried out jointly by more than one person. From the results of interdimensional correlation examination on teamwork variable with the employee 
performance variable, it could be seen clearly if the lowest interdimensional correlation was between open and honest dimensions with the quantity dimension of work. The managerial implication of this research shows if the low quantity of work from an account manager in selling the VPNs is because of the co-workers who did not have the same work ethic while working so the account manager would have lots of tasks and had some difficulty in completing whole tasks at once. Furthermore, the co-workers could be said to almost lack the motivation which is needed by their fellow colleagues, so the account manager would feel less enthusiastic in completing their huge amount of tasks.

Moreover, the result of the strongest interdimensional correlation occurred between the cooperative dimension which has a strong and significant correlation with the dimension of work quality. Meaning if there has an increase in cooperative attitudes will increase the quality of work. This increase was due to the account manager asking colleagues for opinions and views on problems faced in selling VPN products. The results of constructive feedback from his colleagues would make the account managers who do not yet have extensive knowledge and experience increase, and in the end the result makes the quality of work better. Account managers analyze those problems and consider other things before taking action, then the problems they experience in selling VPN products could be resolved properly and has resulted in better performance quality. Additionally, the quality of the account manager's performance is good because the account manager likes to consult with their direct supervisor if a problem occurs. Based on the knowledge and experience conveyed by their superiors, the account manager's knowledge and experience will increase in completing work tasks which in turn improve the quality of work better.

The results showed that business process partially had a positive and significant effect on the account manager performance. These findings were also in accordance with the theory of business processes, that are collections of activities or tasks which produce something. From the results of interdimensional correlation test between business process variables and account manager performance variables, it could be seen clearly that the lowest interdimensional correlation is between definitive and creativity dimensions. The managerial implication of this research shown when the management did not conduct in-depth evaluations of VPN products, the account manager feels insecure in providing solutions for customers and potential customers. In addition, the account managers are not too brave to guarantee optimal service due to lack of confidence in the after sales process. This makes the definitive aspect correlated with the account manager's creativity in selling VPN products.

Furthermore, the result of the strongest inter-dimensional correlation is between the order dimensions which have a strong and significant correlation with the initiative dimension. Meaning if the more the order dimension is increased, the more the initiative of the account manager will be increased. The increase in account manager initiatives is due to the initiative to work on providing optimal service so the services could be enjoyed by customers. Customers want a responsive work response. Once there has a complaint, it is hoped that Telkom through the account manager will provide fast service and will not take it too long to resolve. The goal is to make customers more satisfied with the performance of the account manager. Furthermore, the account manager do coordinates to each unit while doing work activities so the service received by customers would be an satisfactory quality.

The results showed if the leadership, teamwork, business processes simultaneously (together) had a significant effect on account manager performance. From these results of the 
simultaneous test or ANOVA, it is clear that the factors which influence the performance of the account manager include leadership, teamwork, business processes. These factors were considered important in improving the performance of the account manager because the leadership style that could motivate the account manager's work, of course, makes the account manager's performance increase. This is because the leader has the ability to communicate and motivate the account manager's work and the leader continues to provide work direction to the account manager in order to achieve the VPN sales target set. Furthermore, the existence of a factor of great teamwork among the fellow teams has an impact to the results. This is because the fellow colleagues share knowledge and experiences at work.

Colleagues will show an attitude of willingness to help convey their thoughts to colleagues who are having trouble in completing a VPN product sales assignment. Then, business processes could have another impact to account manager performance because Telkom took clear and measurable business processes such as conducting research and development activities, Telkom conducts continuous evaluation and improvement in operations to increase the service quality of VPN products. Telkom has a bureaucracy which is structured systematically, so the services provided to customers were in accordance to the standard operating procedures applied in the company. All problems that occur will be minimized with a clear bureaucracy.

\section{CONCLUSION AND SUGGESTION Conclusion}

Based on the hypothesis test results and discussion above, it could be concluded that the findings from this research are as follows:

1) Leadership partially the strongest and most significant effect on the account manager performance in sales of VPN products.

2) Teamwork partially has a significant effect on the account manager performance in selling VPN products.

3) Business Process partially has a significant effect on the account manager performance in selling VPN products.

4) Leadership, teamwork, business processes simultaneously have a significant effect on the account manager performance in selling VPN products.

\section{Suggestion}

Based on these findings of the lowest mean value, the managerial suggestions which could be brought forward are: Superiors were advised to show a simpler attitude but more qualified in leading., this could be done perfectly so the subordinates (account manager) felt happy with the leadership style. Account managers are advised to show mutual cooperation and coordination among cross-functions in order to create a comfortable and trusted working atmosphere as a team. Leaders are advised to consider more competitive VPN prices in order to increase the sales targets. Further research is suggested to add another variables which could affect employee performance such as work satisfaction and work motivation.

\section{REFERENCE}

Anzhari, I., Sumampow, H.J., \& Kaparang, S.G. (2015). Pengaruh Perilaku Pemimpin Terhadap Kinerja Karyawan PT. Bank Tabungan Negara (Persero) Tbk. Kantor Cabang Manado. Jurnal Administrasi Bisnis, 1-6. 
Bititci Umit, S., Ackermann, F., Ates, A., Davies, J., Garengo, P., Gibb, S., MacBryde, J., Mackay, D., Maguire, C., van der Meer, R., Shafti, F., Bourne, M. \& Umit Firat, S. (2011). Managerial processes: business process that sustain performance. International Journal of Operations \&amp; Production Management, 31(8), 851-91.

Busro, M. (2018). Teori-Teori Manajemen Sumber Daya Manusia. Jakarta: Prenadameidia Group.

Edison. (2016). Manajemen Sumber Daya Manusia. Bandung : Alfabeta.

Gomes, F.C. (2013). Manajemen Sumber Daya Manusia. Yogyakarta: Andi.

Hwang, S.J., Quast, L.N., Center, B.A., Chung, C.-T.N., Hahn, H.-J. \& Wohkittel, J. (2015).

The impact of leadership behaviours on leaders' perceived job performance across cultures: comparing the role of charismatic, directive, participative, and supportive leadership behaviours in the U.S. and four Confucian Asian countries. Human Resource Development International, 18(3), 259-77.

Kartono, K. (2008). Pemimpin dan Kepemimpinan. PT Raja Grafindo Persada, Jakarta.

Magal, S. R., dan Word, J. (2012). Integrated Business Process with ERP Systems. New Jersey: John Wiley \& Sons.

Marpaung, M. (2014). Pengaruh Kepemimpinan Dan Team Work Terhadap Kinerja Karyawan Di Koperasi Sekjen Kemdikbud Senayan Jakarta. Jurnal Ilmiah WIDYA, 2(1), 33-40.

Maryani, A., \& Hasbiansyah, O. (2011). Hubungan antara Pelatihan Model Sintagmatik dengan Sikap Mahasiswa. Prosiding SNaPP2011: Sosial, Ekonomi, dan Humaniora, 2(1), 183194

Putri, A.R., Maison, \& Darmaji. (2018). Kerjasama dan Kekompakan Siswa Dalam Pembelajaran Fisika di Kelas XII MIPA SMAN 3 Kota Jambi. Jurnal Pendidikan Fisika, 3(2), 32-40.

Rainer, R. Kelly, \& Cegielski, Casey G. (2011). Introduction to Information Systems: Enabling and Transforming Business. New Jersey: John Wiley \& Sons..

Santoso, N.B.A, \& Riyanto, S. (2020). Commitment, and Job Satisfaction on the Contract Employees Performance of Pt Bank Rakyat Indonesia Branch Office of Jakarta Daan Mogot. International Journal of Innovative Science and Research Technology, 5(1), 561568 .

Sharma, R. \& Mani, P. (2012). Effective and Efficient Teamwork: Makes Things Happen More Than Anything Else in Organizations. International Journal of Social Science and Inter Disciplinary Research, 1(8), 154-171. 